\title{
ARTISTIC FEATURES OF THE NORTHERN "WHITE NIGHT" MOTIF IN THE LANDSCAPES OF ALEXANDER BORISOV AND LOUIS APOL
}

\begin{abstract}
Summary: The article examines the peculiarities of the color and light atmosphere of the phenomenon of white night in the Far North in the seascapes of the Russian and Northern European art. Attention is drawn to the period from the second third of the 19th century to the first quarter of the 20th century, when scientific and artistic exploration of the Arctic begins to take place on a regular basis. The article shows that the motive of the luminous night at the turn of the century appeared in connection with the appeal of artists to the study of natural contrasts of the Far North. Owing to the comprehending of the monotonous northern landscape, the palette of paintings was enriched with cold light shades of a lightair environment, the artists caught its special glow in the reflections in the water, ice floes and on the snow cover.

The article mentions works of art by K. A. Korovin, V. A. Serov, V. V. Perepletchikov, N. V. Pinegin, A. A. Rylov and $A$. N. Benois, created during their participation in polar expeditions in late XIX and early XX centuries. Attention is drawn to the fact that the painters are branching out from marine pictorial art towards the study of
\end{abstract}

In the art of painting at the turn of the 19th and 20th centuries, an image of a luminous northern night in the Far North appears, a pictorial motif that enriched the palette of artpieces with new tonal elaboration and light effects. The northern seascape appears in cold light shades of a lightair environment, artists catch a special glow of this natural color scale in its reflections in water, on ice floes and on the surface of snow.

The article provides an art analysis of paintings by artists who rethought these specific "northern" tones, and thereby introduced a new "polar" flavor to the painting of marine species. The first to display on their canvases the phenomenon of the Far North - the white night - were the Russian "artist of eternal ice" Alexander Borisov and the Dutch special natural phenomena, such as images of light and dark polar nights, the northern lights, floating ice, fogs and snowy shores.

It is carried out an art analysis and comparison of the works of the Russian "artist of eternal ice" Alexander Borisov and the Dutch "winter artist" Louis Apol, who were the first to depict such a phenomenon as a white night in the Far North. But their artistic interpretation of this phenomenon differs. A. Borisov perceives the North as a kind of "living" space in his own experience of figurative-symbolic comprehension of the world order, but at the same time does not lose touch with his realistic painting manner. And L. Apol impartially captures the surrounding nature, remaining in the principles of the features of compositional construction, which are characteristic of late romanticism. The European painter prefers muffled coloring, while on the canvas of the Russian artist, the paints literally ring and glow.

Keywords: Russian pictorial art of the late 19th — early 20th centuries, landscape, the Far North, seascape, white night, A. Borisov, L. Apol

"winter artist" Louis Apol. Thanks to participation in artistic expeditions to Novaya Zemlya - A. A. Borisov in the 1890s, and L. Apol in 1880 - they introduce a new pictorial motif and special colouristic combinations in the northern seascapes.

Previously, native painters have already turned to the reproduction of northern species in their works. Since the 1850s, artists traveled to the North, but no further than Valaam, and painted from nature, without resorting to coloristic rethinking of light contrasts and rare natural phenomena. By the 1890s, there was an interest in the artistic development of the Far North, which coincided with the need to study the remote outskirts of the country from the economic and transport sides. Thanks to such special expeditions, artists have the opportunity to visit distant 


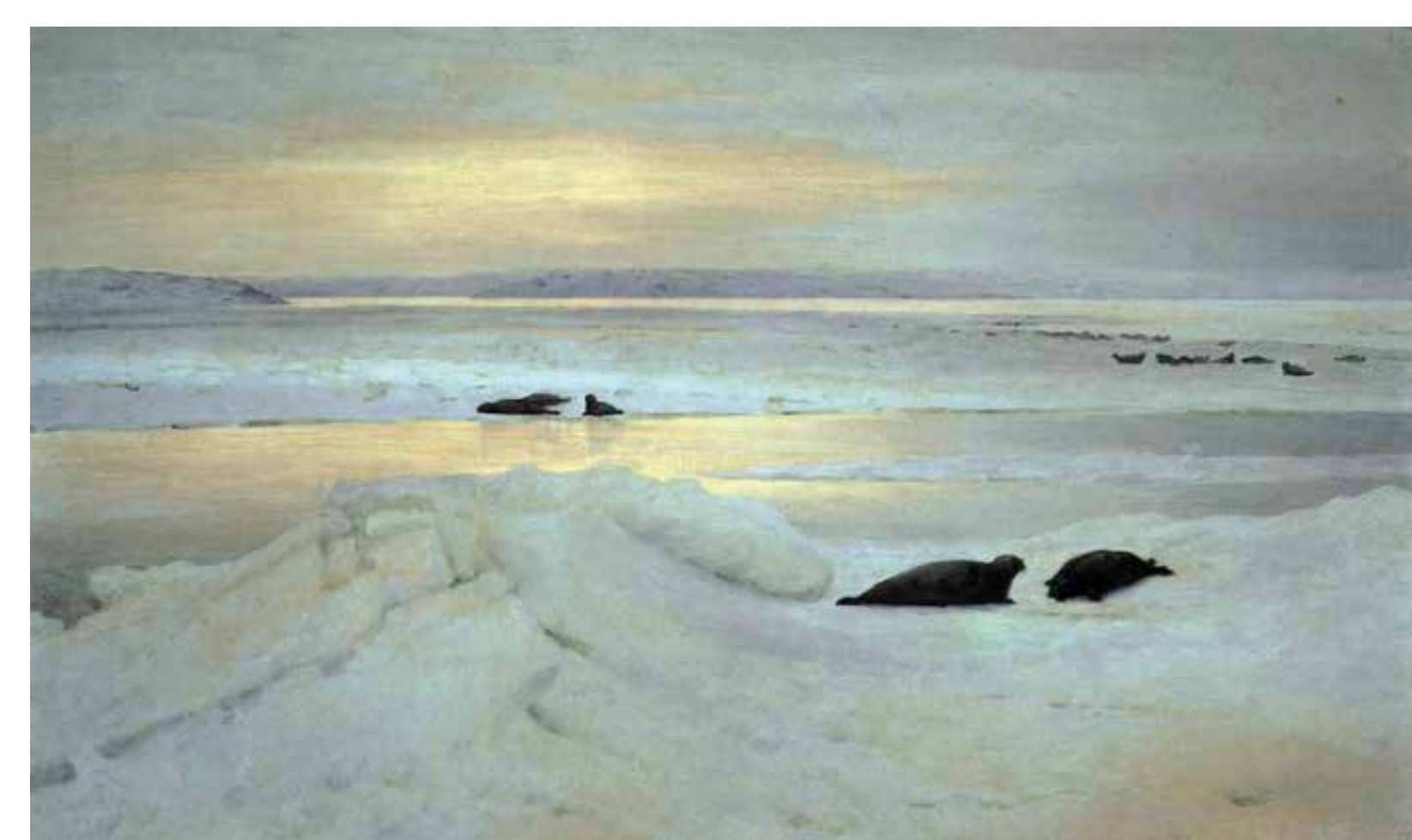

IIl. 1. A.A.Borisov. 1897. Spring polar night. Oil on canvas, State Tretyakov Gallery

regions to study new natural features of the hardto-reach outskirts and reflect them in their works.

Among the paintings of the turn of the 19th and 20th centuries, the works of masters who dedicated a series of their works to this special polar phenom enon can be distinguished. In the 1890 s, K. A. Korovin and V. A. Serov repeatedly made trips to the North on behalf of S. I. Mamontov in order to prepare works for the pavilion "Far North" at the All-Rus sian exhibition in Nizhny Novgorod in 1896 as well the same theme was chosen to participate in the 1900 World's Fair in Paris. Artists are so inspired by new views that Korovin, for example, already on his first trip writes "White Night in Northern Norway" (1890s) and then makes several more trips and de votes multiple canvases to these motives.

Later, at the beginning of the twentieth century, V. V. Perepletchikov, in one of his multiple trips to the North, also turned to the light night motif and wrote "White Night" (1907). Nikolai Pinegin from the Arctic expeditions of 1912-1914 brings polar landscapes, in which he accurately conveys the tonal features of natural contrasts in the image of fog white night and the sea. This theme will become the main one in his work, and later he will enrich his northern sea views with plots with the participation of warships. In the work of A. A. Rylov, the painting "White Night. Night Dawn "(1915), in which he transforms the harsh northern landscape in his own special manner. Inspired by the work of Scandinavian artists and picturesque motives of northern nature, he will devote most of his work to them. A few years later, Albert Benois will take part in the "Murmansk" expedition of 1920, where he will find new tonal combinations in the motives of the northern lights and snow-capped coasts and depict white nights in his watercolors not only in the vicinity of St. Petersburg, but already beyond the Arctic Circle. In one of the watercolors of this cycle "New Earth. Olgino camp" (1925), the artist reflects the northern lights, a rare phenomenon found only in the Arctic latitudes. Throughout the series of expeditionary works, Albert Benois remains an adherent of the landscape painting, in the compositional construction he focuses on the foreground, and the combination of tones in the image of the sky allocates his works with decorative elements

Peering into the rather ascetic nature of the Far North, which is not rich in bright color combinations, the artists participating in the expeditions un expectedly find in it a lot of motifs and color effects that are unusually rich in tonal elaboration. They not only share rare phenomena of the Far North with a wide audience, but also study unique light and color manifestations, unusual landscapes and natural tonal combinations close to decorative ones. Savinova E.A. Albert Benois: a great representative of the ar
tistic dynasty / Savinova E.A. - M. BuksMart, 2016. P. 131

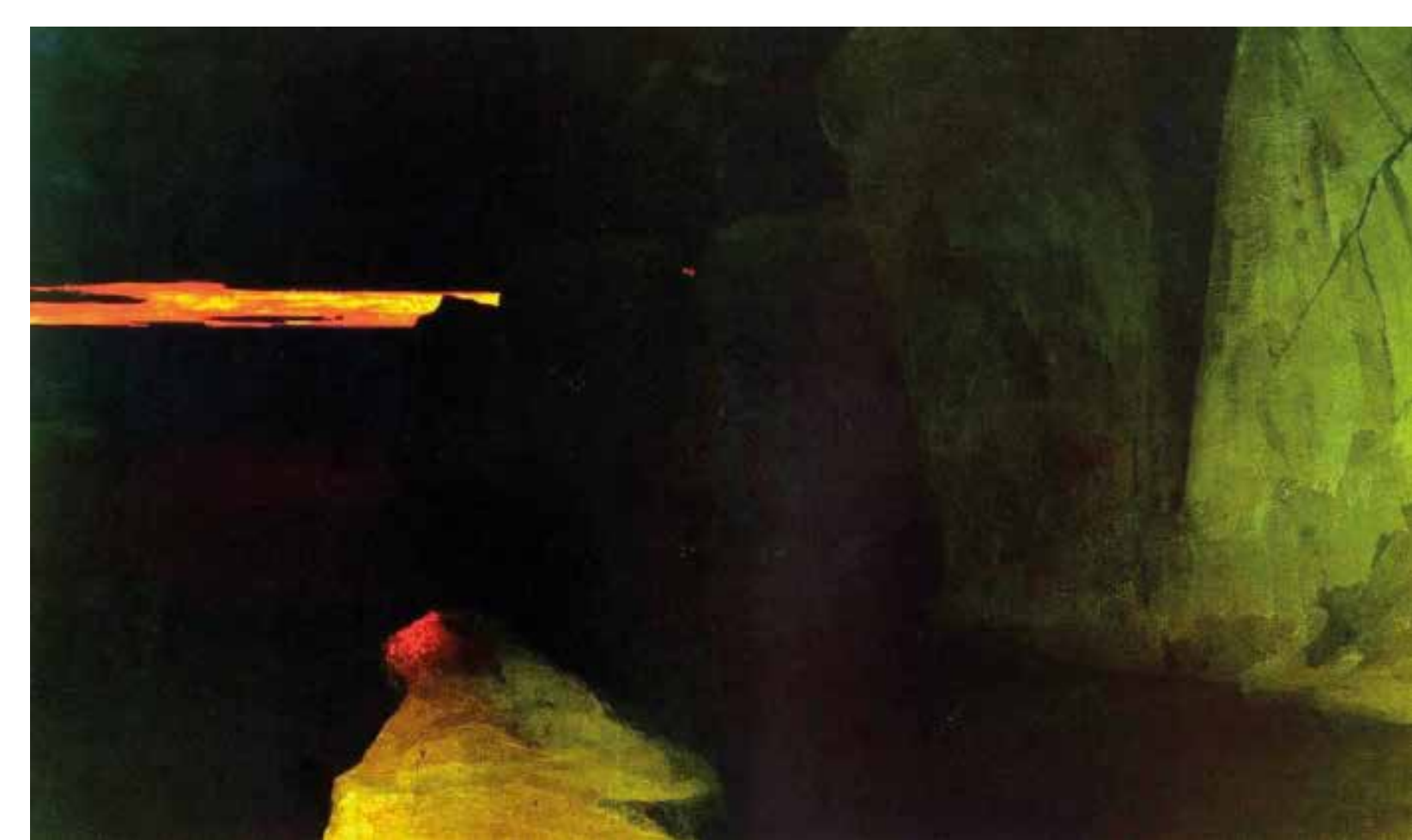

IIl. 2. A.A.Borisov. 1903. "Country of death". oil on canvas, Russian State Museum of the Arctic and Antarctic

The interest in depicting arctic landscapes is large ly due to the difference in natural lighting. In winter, it shows the brightness of any image against the background of snow and ice, and in summer, without such a tonal contrast the colors of objects and the surrounding nature are muffled and ac quire a certain monotony. Rethinking the search for the specifically northern in the landscape, artists discover new natural phenomena that become symbols of the North

The first painter who elaborated in detail the theme of the North and special tonal combinations in the Arctic was Alexander Borisov. His gravitation towards the North was formed in childhood, thanks to the stories of his nanny-zyryanka and tuition in the Solovetsky icon-painting workshop.

Years of staying at the St. Petersburg Academy of Arts in the class of A. I. Kuindzhi enriched the artist's palette, smoothed out the dryness of the drawing, and excessive detail was replaced by the generalization of the landscape. Under the guidance of the master, he acquired his own creative personality traits. Talking about artistic truth, Borisov liked to repeat: "It is not enough to look, you have to see, ... it is even more difficult to write, as you see: truth in art is given just as hard as truth in thought, in science." ${ }^{2}$. The northern seascapes of 2 Borisov N.P. The artist of eternal ice. - L.: Artist of the RSFSR, Borisov N.P. The
Alexander Borisov can be distinguished as a separate direction in the arts - the genre of the northern marina in our opinion they can be talked about as a special phenomenon in landscape painting. The artists painted the sea. Before Borisov, the genre of the seascape in Russian painting was represented exclusively by southern seascapes.

At the same time, the painters themselves before and after Alexander Borisov (until the first third of the twentieth century) did not highlight in their series of works and did not explore the phenomenon of the polar night.

Borisov's artistic finding, as a researcher and as a painter, was the theme of contrasting northern nights - light and dark. From the very first expedition in 1896, Borisov brings sketches depicting a bright northern night, which critics admire, and P. M. Tretyakov completely redeems this series of northern landscapes. In these works, an artistic re search interes Borisov writes in his memoirs: "I experienced a time when midnight is as bright as noon, the lighting is the same. ... On a quiet day, everything merges in the general feeling of some kind of boundless space calm, but cold and inexorable."

The night motif is devoted to works that are characterized not only by gloomy night colors, but 3 Borisov A.A. The Samoyeds. From Pinega to the Kara Sea. SPb 


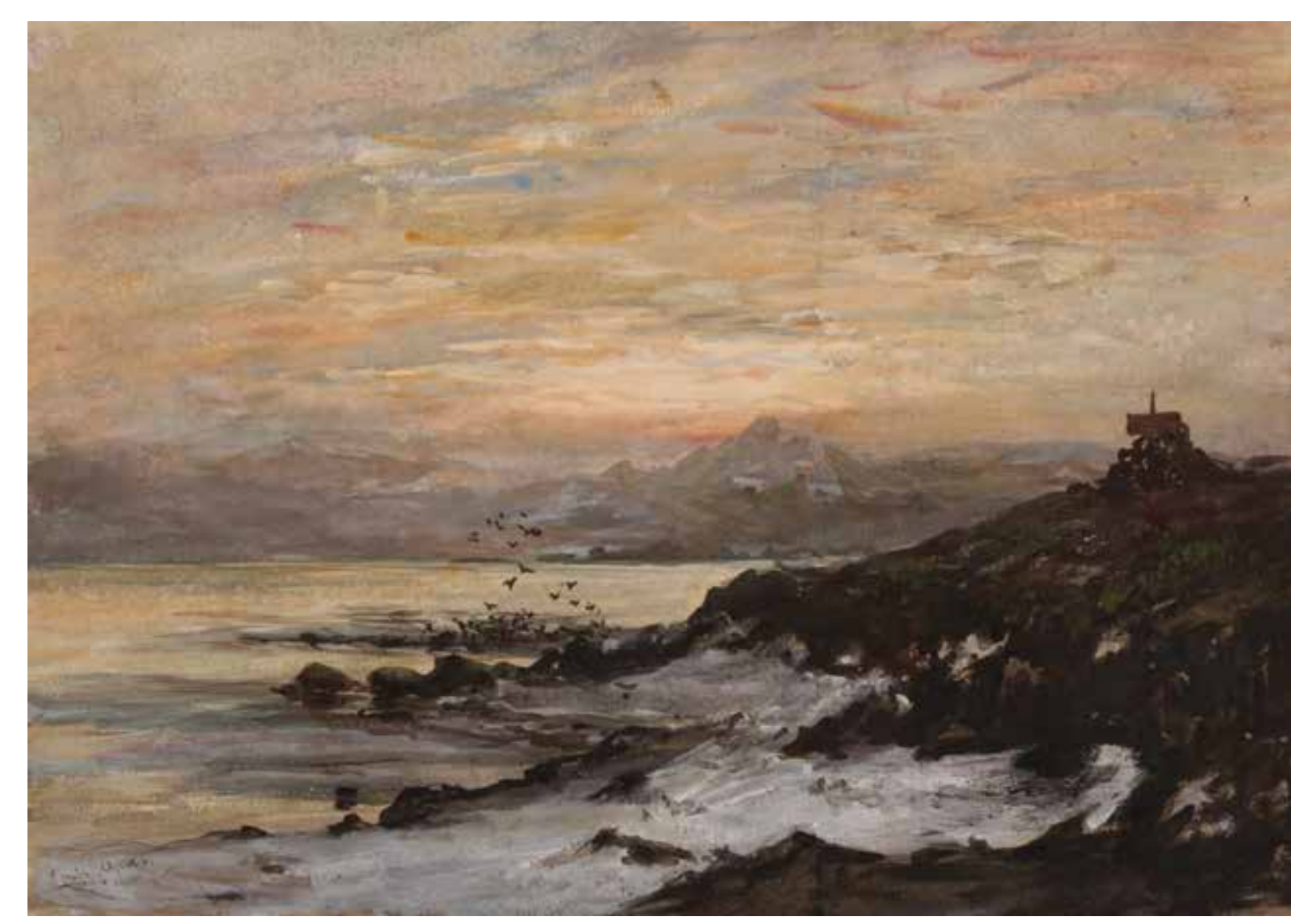

IIl. 3. ill.3 Louis Apol. 1880. "Summer night at the North Pole on Novaya Zembla". Oil on canvas, private collection

in the case of images of the polar night, "... in unusually gentle overflows of [light] tones, which can only be compared with precious stones." ${ }^{4}$. These are works "In the ice of Novaya Zemlya" (1901), "The Land of Death. August Night in the Arctic Ocean" (1903). "Midnight in August in the Arctic Ocean" (1903), "Midnight in August in the Arctic Ocean" (1903), "Spring Polar Night" (1897), "Midnight in the Ice" (1898), "Fog. Midnight in the Ice" (1898), "Night in the Great Land" (1898), "Polar Night in the Far North" (1901).

Night landscapes "Spring Polar Night" (1897) and "Midnight in August in the Arctic Ocean" (1903) were made on the basis of multiple trips to the Far North. In 1896 Borisov joined the expedition commissioned by the Minister of Finance S.Y. Witte to discover a site of the future port in the North of Russia, where for the first time he captured the phe nomenon of the light and dark northern night. The artist gained precious experience and within a few years he equipped his own artistic research journey, where during 1900-1901 studied the contrasts of northern nature, admired the peculiarities of the 4 Borisov A.A. The Samoyeds. From Pinega to the Kara Sea. SPb.
1907. P. 101 light-air environment and its influence on the colo and shape of objects. The nature of the Far North one had ever painted before him - these are fogs, floating ice hummocks, icebergs, abrupt changes of night illumination, snowy shores.

Borisov reinterprets northern seascapes not only in a realistic reproduction of natural possibilities, but also capturing the subtleties of life in a cold region. The study of the harmony of nature of living things in a gloomy icy atmosphere is manifested in the image of seals in the "Spring Polar Night". The artist delicate and shining color combinations. In a specia compositional construction, the artist shows how gap in the sky is reflected on an ice floe covered with water in a place where water seeps, and thus it reflects a double radiance. The lyrical, contem plative concept of the painting is continued in the plein air saturation of the landscape environment with light and air. In this work, Borisov rethinks the experience gained during his tuition in the painting workshop of Kuindzhi.

The same motive appears in a completely different tonal sound in the work "Land of Death" (1903). endowed the artist with numerous motives that no decomposes the fragile light-air space into multiple
The painting depicts a deep black night, and only a narrow bright red band of glow illuminates the tops of the ice floes. In this piece, Borisov elaborates the theme and compositional principles of his teacher, building a coloristic solution on the contrasts of black and crimson shades, where the main dominant is the glow in the night sky. In painting itself, following the trend of his time, Borisov activates the role of the landscape environment and uses a free sketching manner of writing. But in this work the author's pictorial manner is distinguished by the deliberate "cropping" of the composition, simple forms of the image, local colors and contrasting chiaroscuro.

In European painting of the late 19th century, the white night in the landscapes of the Far North appears in the works of the Dutch "winter" artis Louis Apol. In 1880 he went on an expedition of the Netherlands Geographical Society, repeating the route of the discoverer of New Zembla, Willem Barents. He brings three albums with sketches of icebergs, floating ice, fogs, morning and evening lighting. Based on their motives, he writes great works, such as, for example, the painting "Summer Night in the North. New Earth". The construction of figurative expressiveness in this work is carried out on the effects of muffled "night" sunlight and its reflection on a flat-water surface. "Midsummer Night..." is characterized by the romantic diversity of the coloristic system which intensifies the emotional tension of this landscape. During the expedition the artist rethinks the contrasts of the North and the motive of a gloomy night appears in his works. It should be noted that the pictorial task of Louis Apol in the expedition included capturing the area and the course of the expedition. Nevertheless, he brings a lyrical note to the harsh northern views and romanticizes landscapes, including through special natural phenom non as the white night.

Obviously, at the turn of the 19th and 20th centuries, both Russian and European painters were branch out from marine paintings towards interpreting the landscape and studying special natural phenomena and their reflection on their canvases.

Comparing the works of A. Borisov "Midnight in August .." and L. Apol "Summer night in the North.." It should be noted that A. Borisov perceives and depicts on his canvas the northern night and the Far North, in his own experience of figurative-symbolic comprehension of the world order, but at the same time does not lose touch with his realistic painting manner. And L. Apol impartially captures the surrounding nature, remaining in the principles of the features of compositional construction, which are characteristic of late romanticism. The European painter prefers a muffled color, while on the canvas of the Russian artist the paints literally ring and shine.

Comparing the work of these painters, an increase in interest in the phenomenon of white night and natural contrasts of the Far North can be noted. The geography of artistic searches expands northward to the Arctic and southward to the Arkhangelsk region, and in European art - to the Icelandic region and remote Norwegian fjords. The artists' interest in color and light effects represents an attempt to renew the concept of the polar night, study the special world of northern seascapes and embody specific tonal combinations on canvases in the image of water, ice and snow-covered spaces. 
1. Borisov, A.A. 1907. U samoyedov. Ot Pinegi do Karskogo $\quad$ 9. Faass, M., Krämer, F. 2005. Seestücke. Von Caspar David morya [The Samoyeds. From Pinega to the Kara Sea] Saint Petersburg (in Russian)

2. Borisov, N.P. 1983. Khudozhnik vechnogo l'da [The artist of eternal ice], Leningrad: Artist of the RSFSR (in Russian)

3. Pinegin, N.V. 2021. V ledyanykh prostorakh: zapiski polyarnika [In the icy expanses: notes of a polar explorer], Moscow: Eksmo (in Russian)

4. Savinova, E.A. 2016. Al'bert Benua. Velikiy predstavitel' khudozhestvennoy dinastii [Albert Benois: a great representative of the artistic dynasty], Moscow: BuksMart (in Russian)

5. A Mirror of nature. Nordic landscape painting, 1840 1910. [a collaboration on a mutual Exhibition between the national galleries in Scandinavia: Ateneum art museum, Helsinki (21 April - 27 August 2006) etc. 2006. Statens museum for kunst (in English)

6. Archibald, E.H.H. 2000. The dictionary of sea painters of Europe and America. Antique Collectors' Club. Woodbridge. (in English)

7. Alsen, K., Landmann, A. 2016. Nordic painting the rise of modernity. Munich, Prestel (in English)

8. Gunnarsson, T. 1998. Nordic Landscape painting in the nineteenth century. New Haven, Yale University London (in English) Fredrich bis Emil Nolde; München; Prestel (in German) va - k voprosu ana 1 . «kollektsii proizvedeniy iskussnon], Dekorativnoye iskusstvo i predmetno-prostranstvennaya sreda. Vestnik MGKHPA [Decorative art and subject-spatial environment. MGHPA Bulletin], no. 4 part 1 (in Russian)

\section{Electronic resources:}

Louis Apol - artist on the polar expedition (Louis Apol - Kunstenaar mee op poolexpeditie). Electronic resource. Access: https://geografie.nl/artikel/louisapol-kunstenaar-mee-op-poolexpeditie. Date of access: 25.04 .2021

2. Electronic catalog of the Royal National Museum (Netherlands). Electronic resource. Access https://www.rijksmuse-

um.nl/en/search?q=louis\%20 Date of access: 16.07 .2021

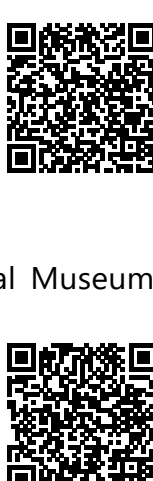
of art - to the question of analyzing the phenome-

соискатель научной степени кандидата искусствоведения, Санкт-Петербургская академия художеств имени Ильи Репина

e-mail: ivetta.enina@mail.ru

Санкт-Петербург, Россия

ORCID0000-0003-0292-6053

DOI: 10.36340/2071-6818-2021-17-5-77-87

\section{ХУДОЖЕСТВЕННЫЕ ОСОБЕННОСТИ МОТИВА СЕВЕРНОЙ «БЕЛОЙ НОЧИ» В ПЕЙЗАЖАХ АЛЕКСАНДРА БОРИСОВА И ЛУИ АПОЛА}

Аннотация: В статье исследуются особенности колорита и световой атмосферы феномена белой ночи на Крайнем Севере в морских пейзажах русского и североевропейского искусства живописи. Обращается внимание на период со второй трети XIX века до первой четверти XX века, когда научное $и$ художественное исследование Арктики начинает происходить на регулярной основе. В статье показано, что мотив светпой ночи на рубеже веков появился в связи с обращением художников к изучению природных контрастов Крайнего Севера. Благодаря переосмыслению монотонного северного пейзажа палитра художественных произведений обогатилась холодными светлени отронками световоздушной среды, художники уловили её особое свечение в отражениях в воде, льинах и на снежном покрове.

В статье упоминаются художественные произведения К. А. Коровина, В. А. Серова В. В. Переплётчикова Н. В. Пинегина, А. А. Рылова и А. Н. Бенуа, созданные Н. B. Пин nх XIX $n$ в нay X солу изучения особенных природных явлений, таких,

В искусстве живописи рубежа XIX-XX столетий Воявляется изображение светлой северной ночи на Крайнем Севере, живописный мотив, который обогатил палитру художественных произведений новыми тональными разработками и световыми эффектами. Северный морской пейзаж предстаёт в холодных светлых оттенках световоздушной среды, художники улавливают особое свечение этой природной цветовой гаммы в её отражениях в воде, на льдинах и на поверхности снега

В статье проводится искусствоведческий анализ живописных произведений художников, которые переосмыслили эти специфические «се- как изображения светлой и тёмной полярных ночей северное сияние, плавучие льды, туманы и заснеженбepera.

Проводятся искусствоведческий анализ и сравнение произведений отечественного «художника вечных льдов» Александра Борисова и нидерландского “зимнего художника» Луи Апола, которые первыми изобразили такое явление, как белая ночь на Крайнем Севере. Но художественное прочтение этого явления у них разнится. А. Борисов воспринимает Север как некое «живое» пространство в собственном опыте образно-символического осмысления мира, но при этом не теряет связи со своей реалистической живописной манерой. А Л. Апол беспристрастно фиксирует окружающую природу, оставаясь в ключе особенностей композиционного построения, характерных нля позднего романтизма. Европейский живописец отдаёт предпочтение приглушённому колориту, тогда как на полотне русского художника Крайнего Севера краски буквально звенят и светятся.

Ключеоне слова: русская живопись кониа XIX - на-

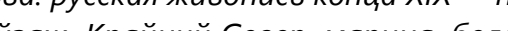
ночь, А. Борисов, Л. Апол.

верные» тона, и тем самым внесли новый «полярный» колорит в живопись морских видов. Первыми отобразили на своих полотнах феномен Крайнего Севера - белую ночь - русский “художник вечных льдов» Александр Борисов и нидерландский «зимний художник» Луи Апол Благодаря участию в художественных экспедициях к Новой Земле - А. А. Борисов в 1890-е годы Л. Апол в 1880 году - они вводят новый жи вописный мотив и особые колористические сочетания в северные морские пейзажи.

Ранее отечественные живописцы уже обращались к воспроизведению северных видов 
в своих работах. С 1850-х годов художники ездили на Север, но не дальше Валаама, и писали натурно, не обращаясь к колористическому переосмыслению световых контрастов и редких природных явлений. К 1890-м годам появляется интерес к художественному освоению уже Крайнего Севера, который совпадает с необходимостью изучения отдалённых окраин странь с экономической и транспортной сторон. Благодаря таким специальным экспедициям художники получают возможность посещения далёких ре гионов для изучения новых природных особенностей труднодоступной окраины и отражения их в своих работах.

Среди живописных произведений рубежа XIX И XX столетий можно выделить работы мастеров, посвятивших серии своих работ этому осо бенному полярному явлению. В 1890-е годы на Север неоднократно отправляются К. А. Коровин и В. А. Серов по поручению С. И. Мамонтова в целях подготовки произведений для павильона «Крайний Север» на Всероссийской выставке в Нижнем Новгороде в 1896 году, и та же тема была выбрана для участия во Всемирной выставке 1900 года в Париже. Художников так вдохновляют новые виды, что Коровин, например, уже в первой поездке пишет «Белую ночь в Северной Норвегии» (1890-е) и затем совершает ещё несколько поездок и посвящает этим мотивам множественные полотна.

Позднее, уже в начале XX века, В. В. Переплётчиков в одной из своих многочисленных поездок на Север также обращается к светлому ночному мотиву и пишет «Белую ночь» (1907 г.). Николай Пинегин из арктических экспедиций 1912-1914 годов привозит полярные пейзажи, в которых он с точностью передаёт тональные особенности природных контрастов в изображении тумана, белой ночи и моря. Эта тема станет основной в его творчестве, и позже он обогатит свои северные морские виды сюжетами сучастием военных кораблей. В творчестве А. А. Рылова можно выде лить картину «Белая ночь. Ночная заря» (1915 г.) в которой он в своей особой манере преображает суровый северный пейзаж. Вдохновлённый творчеством скандинавских художников и живописными мотивами северной природы, большую часть своего творчества он будет посвящать именно им.

Несколькими годами позднее Альберт Бенуа примет участие в «Мурманской» экспедиции
1920 года, где найдёт для себя новые тональные сочетания в мотивах северного сияния и заснеженных побережий и изобразит в своих акварелях белые ночи не только в окрестностах Петербурга, а уже за полярным кругом. В одной из них «Новая Земля. Ольгино становище» (1925 г.) художник отражает северное сияние, редкое явление встречающееся только в арктических широтах. Во всей серии экспедиционных работ А. Бенуа остаётся приверженцем пейзажа-картины, в композиционном построении делает акцент на первый план, а сочетания тонов в изображении неба наделяют его работы элементами декоративности

Вглядываясь в довольно аскетичную и не богатую на яркие цветовые сочетания природу Крайнего Севера, художники - участники экспедиций неожиданно находят в ней множество необычайно богатых в тональной разработке мотивов и колористических эффектов. Они не только делятся с широким зрителем редкими явлениями Крайнего Севера, но и изучают уникальные световые и цветовые проявления, непривычные ландшафты и естественные тональные сочетания, близкие к декоративным. Интерес к изображению ар ктических пейзажей во многом обусловлен ещё и отличием естественного освещения. Зимой оно проявляет яркость любого изображения на фоне снега и льдов, а летом, без такового тонального контраста, цвета предметов и окружающей при роды приглушаются и обретают определённую монотонность. Переосмысливая поиски специфически северного в пейзаже, художники открывают новые природные явления, которые становятся символами Севера.

Первым живописцем, который подробно раз рабатывал тему Севера и особенные тональные сочетания в Заполярье, был Александр Бори сов. Его тяготение к Северу сформировалось ещё в детстве, благодаря рассказам няни-зы рянки и обучению в Соловецкой иконописной мастерской.

Годы пребывания в Петербургской академии художеств в классе А. И. Куинджи обогатили палитру художника, сгладили сухость рисунка, а излишняя детализация заменилась обобщённостью пейзажа. Под руководством мастера он обрёл собственные творческие индивидуальные черты Говоря о художественной правде, Борисов любил 1 Савинова Е.А. Альберт Бенуа: великий представитель ху
дожественной династии / Е. А. Савинова. М.: БуксМАрт, дожественн
2016. С. 131. повторять: «Мало смотреть, надо видеть, ... ещё труднее написать, как видишь: правда в искус стве даётся так же трудно, как и правда в мысли в науке» ${ }^{2}$. Северные морские пейзажи Алексан дра Борисова можно выделить в отдельное направление в изобразительном искусстве - жанр северной марины, на наш взгляд, о них можно говорить как об особом явлении в пейзажной живописи. До Борисова в русской живописи жанр марины был представлен исключительно южньми морскими пейзажами.

В то же время сами живописцы до и после Александра Борисова (до первой трети XX века) не выделяли в серии своих работ и не изучали явление полярной ночи.

Художественным открытием Борисова, как исследователя и как живописца, была тема контрастных северных ночей - светлая и тёмная. Из самой первой экспедиции 1896 года Борисов при возит этюды с изображением светлой северной ночи, которые восхищённо принимают критики, а П. М. Третьяков полностью выкупает эту серию северных пейзажей. В этих работах обнаружива ется художественно-исследовательский интерес к контрастам природы, Борисов пишет в своих воспоминаниях: «Я переживал то время, когда полночь так же светла, как и полдень, освещение одно и то же. ...В тихий день всё сливается в общем ощущении какого-то беспредельного пространства, спокойного, но холодного и неумолимого» ${ }^{3}$

Ночному мотиву посвящены работы, которые характеризуются не только сумрачными ночными красками, но и, в случае с изображениями полярной ночи, «...в необыкновенно нежных переливах [светлых] тонов, которые только и можно сравнить с драгоценными камнями» ${ }^{4}$. Это работы «Во льдах Новой Земли» (1901 г.), «Страна Смерти. Августовская ночь в Ледовитом океане» (1903 г.), «Полночь в августе в Ледовитом океане» (1903 г.), «Весенняя полярная ночь» (1897 г.), «Полночь во льдах» (1898 г.) «Туман. Полночь во льдах» (1898 г.), «Ночь в Большеземелье» (1898 г), «Полярная ночь на Крайнем Севере» (1901г.).

Ночные пейзажи «Весенняя полярная ночь (1897 г.) и «Полночь в августе в Ледовитом оке-

2 Борисов Н.П. Художник вечных льдов. Л.: Художник РСФСР 1983. С. 193-194.

орисов А.А. У самоедов. От Пинеги до Карского моря
СПб. 1907. С. 100 .

Борисов А. А. У са
СПб., 1907. С. 101. ане» (1903 г.) были выполнены по итогам неод нократных поездок на Крайний Север. В 1896 Борисов присоединился к экспедиции по заказу министра финансов С. Ю. Витте для поиска места будущего порта на Севере России, где впервые запечатлел феномен светлой и тёмной северной ночи. Художник получил драгоценный опыт и уже через несколько лет снарядил своё собственное художественно-исследовательское путешествие, где в течение 1900-1901 годов изучал контрасты северной природы, восхищался особенностями световоздушной среды и её влиянием на цве и форму предметов. Природа Крайнего Севера одарила художника многочисленными мотиватуманы, плавучие льды-торосы, айсберги, резкие смены ночного освещения, заснеженные берега.

Борисов переосмысливает северные морские пейзажи не только в реалистичном воспроизведении природных особенностей, но и улавли вая тонкости жизни в условиях холодного края. Изучение гармонии природы живого в сумрачной ледяной атмосфере проявляется в изображении тюленей в «Весенней полярной ночи». Хрупкое световоздушное пространство художник раскладывает на множественные нежные и сияющие цветовые сочетания. В особом композиционном построении художник показывает как просвет в небе отражается на льдине, по крытой водой, в месте, где просачивается вода, и таким образом он отражает двойное сияние Лирическая, созерцательная концепция картинь находит продолжение в пленэрной насыщенно сти пейзажной среды светом и воздухом. В этом произведении Борисов переосмысливает опыт полученный во время обучения в живописной мастерской Куинджи.

В совсем ином тональном звучании предстаёт этот же мотив в работе «Страна смерти (1903 г.). На картине изображена глухая чёрная ночь, и лишь узкая ярко-красная полоса зарева освещает вершины льдин. В этом полотне Борисов развивает тему и композиционные принци пы своего педагога, выстраивая колористическо решение на контрастах чёрного и багрового от тенков, где главной доминантой выступает ночное зарево. В самой живописи, следуя тенденции ввоего времени, Борисов активизирует роль пейзажной среды и применяет свободную эскизную манеру письма. Но именно здесь живописный язык автора отличает нарочитая «кадрирован- 
ность» композиции, простые формы изображения, локальные цвета и контрастная светотень.

В европейской живописи конца XIX столетия белая ночь в пейзажах Крайнего Севера появляется в работах нидерландского «зимнего» художника Луи Апола. В 1880 году он отправляется в экспедицию Нидерландского географическо го общества, повторяющую маршрут первооткрывателя Новой Земли Виллема Баренца. Он привозит три альбома с зарисовками айсбергов, плавучих льдов, туманов, утреннего и вечернего освещения. По их мотивам он пишет большие работы, как, например, полотно «Летняя ночь на Севере. Новая Земля». Построение образной выразительности в этой работе выполнено на эффектах приглушённого «ночного» солнечного освещения и его отражении на ровной поверхности воды. «Летнюю ночь...» характеризует романтическая пестрота колористического строя, который усиливает эмоциональную напряжённость этого пейзажа. За время экспедиции художник переосмысливает контрасты Севера, и в его работах появляется мотив сумрачной ночи. Не обходимо отметить, что в живописную задачу Луи Апола в экспедиции входило все же отражение местности и хода экспедиции. Тем не менее он вносит лирическую ноту в суровые северные виды и романтизирует пейзажи в том числе через изображение такого особенного природного явления, как белая ночь.

Очевидно, что на рубеже XIX и XX столетий русские, и европейские живописцы отходят от морской видописи в сторону переосмысления пейзажа и изучения особенных природных явлений и отражения их на своих холстах.

Сравнивая работы А. Борисова «Полночь в августе.» и Л. Апола «Летняя ночь на Севере. следует отметить, что А. Борисов воспринимает и изображает на своём полотне северную ночь и Крайний Север как некое «живое» про странство в собственном опыте образно-символического осмысления мира, но при этом не теряет связи со своей реалистической живописной манерой. А Л. Апол воспринимает пространство скорее беспристрастно, лишь изобража северный ландшафт и время суток, оставаяс в ключе особенностей композиционного построения, характерных для позднего романтизма. Европейский живописец отдаёт предпочтение приглушённому колориту, тогда как на полотне русского художника краски буквально зве нят и светятся.

Сравнивая творчество этих живописцев, можно отметить нарастание интереса к феномену белой ночи и природных контрастов Крайнего Севера. География художественных поисков расширяется севернее к Арктике и южнее к Архангельской области, а в европейском искусстве - к исландскому региону и отдалённым норвежским фьордам. Интерес художников к цветовым и световым эффектам представляет собой попытку обновления представлений о полярной ночи, изучения особого мира северных морских пейзажей и воплощения на холстах специфических тональных сочетаний в изображении воды, льдов и заснеженных пространств.
Электронные ресурсы:

1. Луи Апол - художник в полярной эспедиции (Louis Apol - Kunstenaar mee op poolexpeditie) [электронный ресурс. - Режим доступ https://geografie.nl/artikel/louis-apolkunstenaar-mee-op-poolexpeditie (Дата обращения: 25.04.2021).
2. Электронный каталог Национального королевского музея (Ни дерланды) [Электронный ре сурс].- Режим доступа. https://www. rijksmuseum.nl/en/search?q=louis\%20 ния: 16.07.2021)

БИБЛИОГРАФИЯ

1. Борисов А.А. У самоедов. От Пинеги до Карского 6. A Mirror of nature. Nordic landscape painting, 1840моря.-СПб., 1907.

2. Борисов Н. П.ХУдожник вечных льдов- -Л.ХХудожник РСФСР, 1983.

3. Пинегин Н.В. В ледяных просторах: записки полярника / H. В. Пинегин; вступитерьная сатья $и$ корментарии: А. Хорошевскй - Москв: Эксм0, 2021.

4. А.В. Лиховива. Колекции произвененй искусства - К вопросу анализа феномена // Декоративное искусство и предметно-пространственная среда. Вестник МГХПА, № 4, 4. 1, 2021

5. Савинова Е. А. Альберт Бенуа: великий представиС. М.: БуксМАрт, 2016. 1910 [a collaboration on a mutual Exhibition between museum Helsinki (21 April 27 August 2006) etc] museum, 2006.

7. Archibald E.H.H. The dictionary of sea painters of Europe and America. Antique Collectors' Club.Woodbridge, 2000.

8. Alsen K. Nordic painting the rise of modernity.Munich, [etc.] Prestel, 2016.

9. Gunnarsson T. Nordic Landscape painting in the nineteenth century. New Haven, Yale University London cop, 1998

0. Seestücke. Von Caspar David Friedrich bis Emil Nold München: Prestel, 2005 